\title{
建物外壁に生育する藻類の増殖と死滅のモデル化に関する研究 MODELING OF ALGAL GORWTH AND DEATH ON EXTERIOR WALLS OF BUILDINGS
}

\author{
中嶋 麻起子*, 鉾井修一**, 小椋 大 輔***, 伊庭 千恵美**** \\ Makiko NAKAJIMA, Shuichi HOKOI, Daisuke OGURA \\ and Chiemi IBA
}

\begin{abstract}
This research aims to quantify the relationship between airborne algal growth/death on the exterior walls of the building and environmental factors such as surface temperature and humidity. Based on this, the study proposes a prediction model for the algal growth, where the algal growth was evaluated as algal cell number. The proposed model was used to simulate the change in algal cell number (growth and/or death), taking into consideration the temperature, humidity, and incident solar radiation. Results indicate that the algal growth rate agreed well with the measured $\mathrm{L}^{*}$ value (brightness).
\end{abstract}

Keywords : Airborne algae, L* value, Surface temperature and humidity, Solar radiation, Modeling, Exponential model 気生藻類， $\mathrm{L}$ *值，表面温湿度，日射，モデル化，指数関数モデル

\section{1. 研究の背景と目的}

建物の屋上近くの外壁、空枠の下、壁下部の地面近くに見られる 黒色や緑色の污れの多くが、藻類や真菌類を含む微生物の付着・生 育によるものであることは既往研究により示されている 112) 3) 4) 5)6)。

本論文は、外壁面での污れの主原因となっている気生藻類の増 殖・死滅に関する環境条件の定量化を行い、それらを用いて増殖・ 死滅をモデル化することを目的としている。

これまでに京都市内での実態調査により、外壁污れは雨水が直接 当たりやすい部位に多く観察されるが、雨水が直接当たりにくい部 位でも観察されること、また、どちらの部位でも污れの中に藻類と 思われる細胞が含まれていることを示した 7)。また、仁和寺九所明 神での環境測定において、污れの程度を目視およびL*值により評価 すると注 1 )、両者はよく対応し外壁の変色程度をL*值により定量的 に評価することが可能であることを示した 8)9)。さらに、壁表面温 度が高温になりやすい部位ほど藻類が死滅しやすいため、変色程度 が小さく L*值が大きくなることを示した ${ }^{899)}$

これらの結果によると、以下のような外壁面での藻類の増殖・死 滅のプロセスが想定される。すなわち、藻類の付着はあらゆる外壁 で生じるが、日射が当たりやすく低湿度・高温になりやすい部位で は付着した藻類が死滅しや寸いため、目視により判別できるような 污れは発生せず、逆に日射が当たりにくく低湿度・高温が発生しに くい部位では付着した藻類が増殖し、やがて目視により判別できる
程度の污れとなる。

本論文では、上記のプロセスに基づいて仁和寺九所明神の壁表面 における L*值測定結果から、藻類の増殖・死滅の推移を明らかにす るとともに、外壁での藻類の増殖・死滅のモデル化を行う。

\section{2. 仁和寺九所明神における環境測定}

\section{1. 測定概要}

\subsection{1. 測定対象と測定期間}

測定対象は京都市北西部に所在する仁和寺境内の九所明神である。 九所明神は寛永年間に建立され、国の重要文化財に指定されている。 最近では平成 15 年〜 18 年に大規模な修復工事が行われたが 10)、そ の際にすべて再塗装された白色の胡粉塗外壁で、現在すでに黒色一 の変色が発生している。測定は 2011 年 10 月から開始し、2015 年 4 月現在も継続している。

\subsection{2. 外気温湿度・外壁表面 (近傍) 温湿度の測定}

温湿度データロガー(RTR-53A，T\&D Corporation)を用いて 15 分間隔で外壁表面近傍の温湿度測定を行った。設置場所をFigs.1, 2 に示す。図中の南東角の、印の位置に気象観測システム (Weather Bucket, (有)アグリーウェザー)を設置し、外気温湿度、水平面全天 日射量、降水量、風向、風速を 30 分間隔で測定した。印の位置 では、外壁が変色している上部の梁の上と、ほとんど変色していな い下部の梁の上の 2 か所に、印印の位置では同様に上部、下部、最
京都大学大学院工学研究科建築学専攻 大学院生·修士 (工学)

* 京都大学大学院工学研究科建築学専攻 教授・工博

*** 京都大学大学院工学研究科建築学専攻 准教授 · 博士 (工学)

**** 京都大学大学院工学研究科建築学専攻 助教 $\cdot$ 博士 $($ 工学 $)$
Grad. Stud., Dept. of Architecture and Architectural Eng. Graduate School of Engineering, Kyoto University, M.Eng. Prof., Dept. of Architecture and Architectural Eng., Graduate School of Engineering, Kyoto University, Dr.Eng. Assoc. Prof., Dept. of Architecture and Architectural Eng., Graduate School of Engineering, Kyoto University, Dr.Eng. Assist. Prof., Dept. of Architecture and Architectural Eng., Graduate School of Engineering, Kyoto University, Dr.Eng. 
下部の 3 カ所に温湿度データロガーを設置した(計 11 力所)。測定対 象が重要文化財であるため、建物の美観に配慮し、拝観者の目に触 れや寸い建物正面(南壁)では温湿度測定を行わなかった。本来は、 壁表面の温湿度を測定するために壁面にセンサーを設置したいとこ ろであるが、壁面の加工や直接の接触を避けるため、壁面にできる だけ近い位置(壁面から $5 \mathrm{~mm}$ 以内)の温湿度を外壁表面温湿度に等 しいと見なし ${ }^{11)}$ 、以下の考察を行う。

\subsection{3. 外壁の変色状態の測定}

外壁の変色状態を評価するため、土色計(SPAD-503, コニカミノ ルタ)を用いて $\mathrm{L}^{*} \mathrm{a} * \mathrm{~b}^{*}$ 表色系の $\mathrm{L}$ *值(明るさ)を測定した。Fig. 2 に 示寸ように各外壁に $40 \times 60 \mathrm{~cm}$ の領域を定め、その領域内に 6 力所 の測定箇所を設定した。各測定箇所で 3 回ずつ $\mathrm{L}$ *值を測定し平均を とった。さらにその 6 カ所の平均值をその領域の值とした。東殿南 壁、西殿南壁、北壁(東殿)、北壁(西殿)では各 1 か所ずつ、東殿東壁 と西殿西壁では、上部の梁上の外壁とほぼ同様の変色が見られる壁 上部とあまり変色が見られない壁下部の 2 か所ずつの計 8 か所にお いて、約 1 か月に 1 回の間隔で測定した(Fig. 2)。

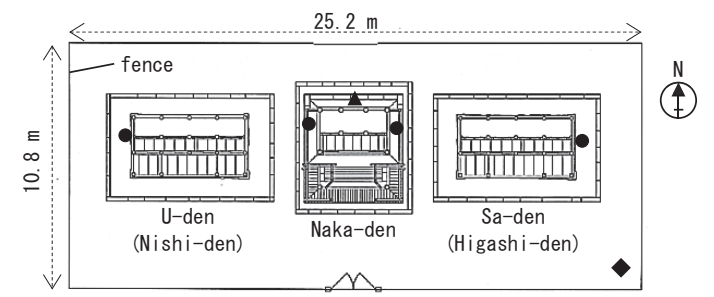

: Weather observation system

- : Temperature and humidity (two positions in vertical directions) $\Delta$ : Temperature and humidity (three positions in vertical directions)

Fig. 1 Plan of Kusyo Myojin Shrine and locations of the measurement devices

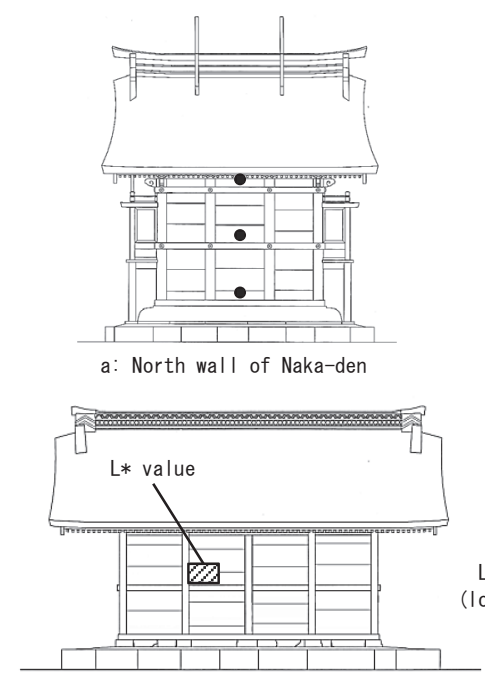

c: North wall of Higashi-den and Nishi-den

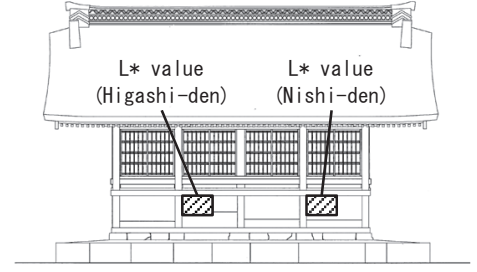

e: South wall of Higashi-den and $\mathrm{Nishi-den}$

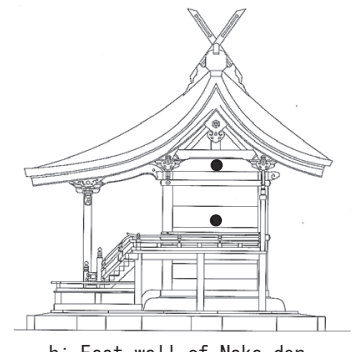

$\mathrm{b}$ : East wall of Naka-den

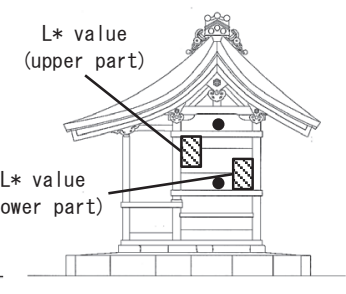

d: East wall of Higashi-den

- : Temperature and humidity devices and the area where L* values measured were symmetrica on the east and west walls.

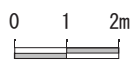

The locations of measurement

Fig. 2 Wall parts where L* values measured

\section{2. 測定結果}

\subsection{1. 外壁表面の $L *$ 値の時間変化}

各外壁表面のL*值の時間変化をFig. 3 に示寸。大羽ら、S. C. Agrawalらによると死滅した藻類細胞は白色や透明に、あるいは形 が崩壊し、死滅した藻類細胞群は透明や不鮮明となり、縮小したり 崩壊する 3 312) 13) 14)。このことから、本論文では、藻類が死滅する際 にはL*值が増加し壁表面の明度が大きくなり、増殖する際にはL* 值が減少し明度が小さくなると見なす。 $L^{*}$ 値の小さい順に北壁(西 殿)、北壁(東殿)、東壁上部(東殿)、西壁上部(西殿)、東壁下部(東殿)、 西壁下部(西殿)、南壁(東殿)、南壁(西殿)となっている。

測定開始(2013 年 6 月 4 日)から 2013 年 8 月 6 日まで、すべての 部位で $L *$ 值は増加している。その後、2013 年 9 月 9 日に大きく減 少し、2013 年 9 月 26 日には再び増加している。2013 年 9 月 26 日 から 2014 年 12 月 19 日までは一定あるいは非常に緩やかに増加し ているが、 2014 年 1 月 20 日から 2014 年 5 月 23 日までは全体的 に L*值は約 1２増加する。 2014 年 7 月 30 日にやや減少した後、 再び増加しているが、その後 2014 年 12 月 18 日まで緩やかに減少 し、その後はわずかに増加している

\subsection{2. $L *$ 值の時間変化と壁表面温湿度・降水量との関係}

L*值の変化と壁表面の温湿度の変化との対応について検討を行 うため、日射が当たりやすい部位(南壁(東殿)、南壁(西殿)、東壁下 部(東殿)、西壁下部(西殿)）、日射が当たりにくい部位(北壁(東殿)、 北壁(西殿)、東壁上部(東殿)、西壁上部(西殿))の L*值の変化を Fig. 4 に示す。また、各測定日の直前 10 日間において $30^{\circ} \mathrm{C}$ 以上、 $40^{\circ} \mathrm{C}$ 以 上、 $\mathrm{RH} 80 \%$ 以上の壁表面温湿度の発生割合について日射が当たり やすい部位、日射が当たりにくい部位のそれぞれの平均值を Figs. 5, 6,7 に示す。

\section{(1) 2013 年 6 月 4 日から 2013 年 8 月 6 日}

$\mathrm{L}^{*}$ 值の測定箇所が少なかったため日射が当たりにくい部位の平 均值のみであるが、 L*值は大きく増加している。日射が当たりにく い部位でも $40^{\circ} \mathrm{C}$ 以上の高温がわずかに発生し、 $30^{\circ} \mathrm{C}$ 以上の高温は日 射が当たりやすい部位と同程度の割合で発生している(Figs. 5, 6)。 このことから、高温により藻類が急激に死滅したと考えられる。

(2) 2013 年 9 月 9 日

前回測定時 $(2013$ 年 8 月 6 日)に比べ $\mathrm{L}$ *值が大きく減少している。 これは、測定前に台風が通過し曇りや雨の天候が多く日照時間が少 なかったため、 $40^{\circ} \mathrm{C}$ 以上の高温の発生頻度は低く(Fig. 6)、高湿度が 多く発生したことから(Fig. 7)、藻類が増殖したと考えられる。

\section{(3) 2013 年 9 月 26 日}

前回測定時(2013 年 9 月 9 日)より L*值が大きく増加している。 直前 10 日間の降水量は 2013 年 9 月 9 日よりも多いが、降雨があっ たのは 9 月 16 日のみで、その後測定日まで天候は晴れが多く、80\% 以上の高湿度の発生はあまり多くない(Fig. 7)。また、 $40^{\circ} \mathrm{C}$ 以上の高 温が非常に多く発生している(Fig. 6)。そのため、高温により藻類が 死滅したと思われる。

(4) 2013 年 10 月 22 日から 2013 年 12 月 19 日

期間中、 $L^{*}$ 值はやや低くほぼ一定の值で推移している。これは、 $40^{\circ} \mathrm{C}$ 以上の高温が発生しなかったため(Fig. 6)藻類が死滅しにくく、 必要な水分を得た際には増殖可能であったためと考えらえる。特に 2013 年 10 月 22 日と 2013 年 11 月 22 日は、測定前に RH $80 \%$ 以上 
の高湿度が比較的多く発生したため(Fig. 7)藻類が増殖しやすい環 境であったと思われる。

(5) 2014 年 1 月 20 日から 2014 年 5 月 23 日

期間中、 $L^{*}$ 值は徐々に増加している。 $80 \%$ 以上の高湿度の発生が 少なく(Fig. 7)、40ㄷ上の高温が発生する時期があり (Fig. 4)藻類
が増殖しにくく死滅しやすかったことによると考えられる。

(6) 2014 年 6 月 27 日から 2014 年 7 月 30 日

Fig. 3 より $\mathrm{L}^{*}$ 值が減少している部位は、東壁上部(東殿)、西壁上 部(西殿)である。測定直前の 7 月 27 日はほぼ 1 日中雨で藻類が増殖 しやすく、日射が当たりにくい部位ではその後も $40^{\circ} \mathrm{C}$ 以上の高温が

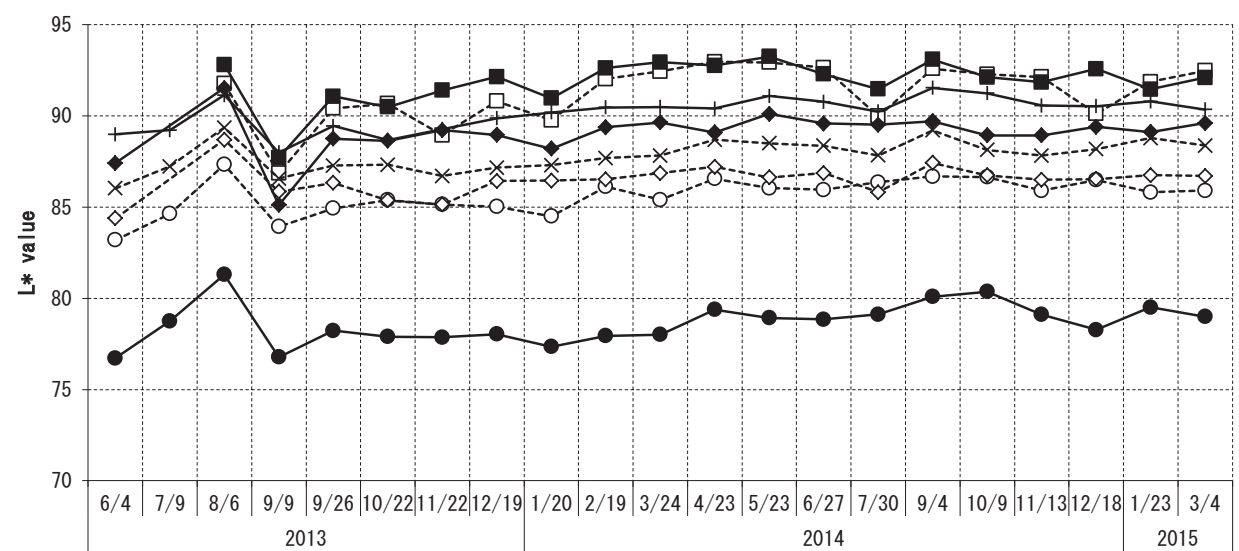

Fig. 3 Change in L* value of each wall
-.----.-- South wall of Higashi-den

$\longrightarrow$ South wall of Nishi-den

----o--- North wall of Higashi-den

$\longrightarrow$ North wall of Nishi-den

-.----.- Upper part of east wall of Higashi-den

$\longrightarrow$ Lower part of east wall of Higashi-den

----x---- Upper part of west wall of Nishi-den

Lower part of west wall of Nishi-den

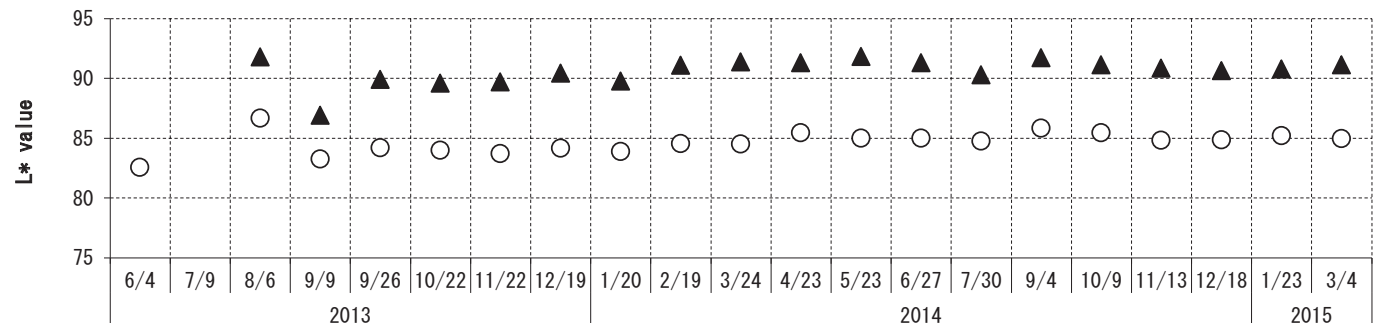

Fig. 4 Change in average $L *$ value of each wall
$\Delta$ Average of parts exposed to direct solar radiation oAverage of parts not exposed to direct solar radiation

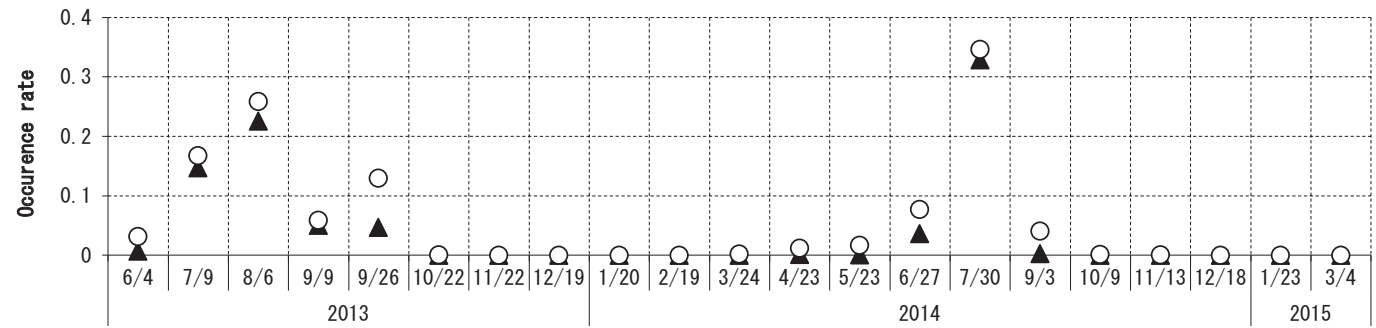

$\Delta$ Average of parts exposed to direct solar radiation oAverage of parts not exposed to direct solar radiation

Fig. 5 0ccurrence rate of temperatures over $30^{\circ} \mathrm{C}$ in the previous 10 days of measurements

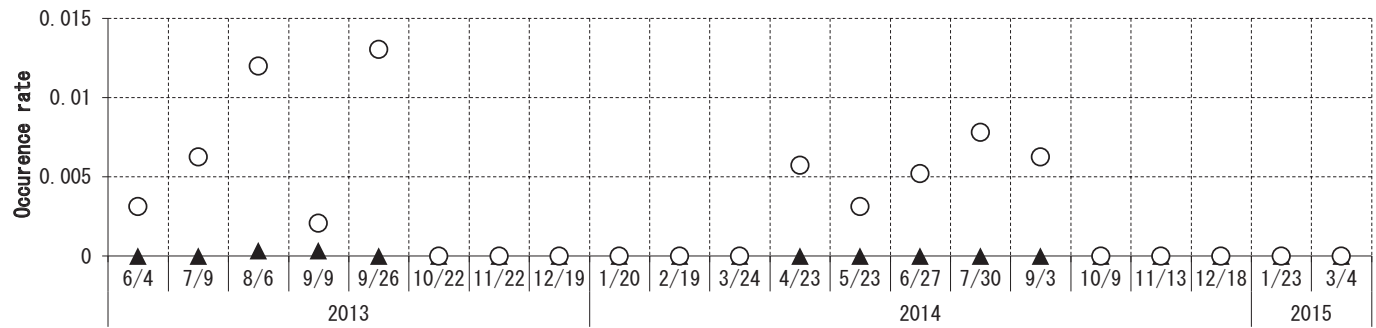

$\Delta$ Average of parts exposed to direct solar radiation oAverage of parts not exposed to direct solar radiation

Fig. 6 0ccurrence rate of temperatures over $40^{\circ} \mathrm{C}$ in the previous 10 days of measurements

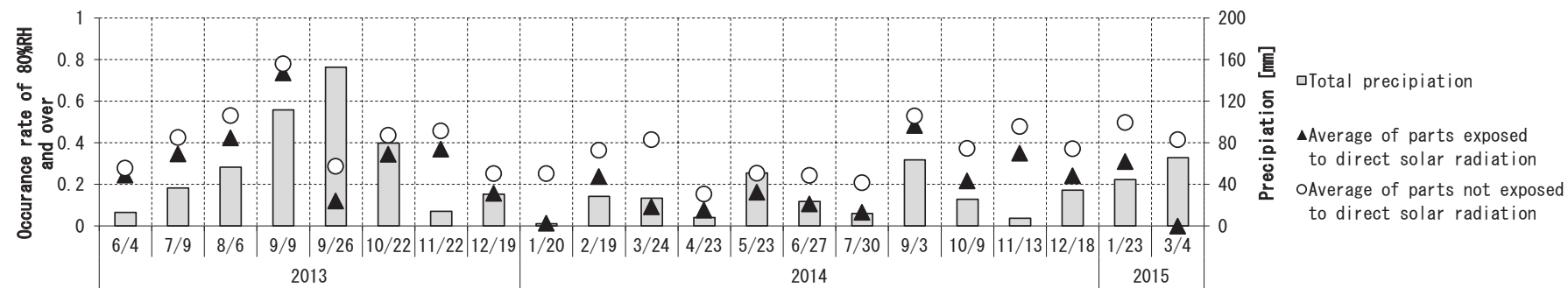

Fig. 7 0ccurrence rate of relative humidity $80 \%$ and precipitation in the previous 10 days of measurements 
発生しないため、死滅しなかったと思われる。

(7) 2014 年 7 月 30 日から 2014 年 9 月 4 日

期間中、 $40^{\circ} \mathrm{C}$ 以上の壁表面温度が多く発生し(Fig. 6)、80\%以上 の高湿度はほとんど発生しなかったため(Fig. 7)、藻類は減少し L* 值は増加したと考えられる。

\section{(8) 2014 年 10 月 9 日から 2014 年 3 月 4 日}

期間中、 $40^{\circ} \mathrm{C}$ 以上の壁表面温度が全く発生しなかったため(Fig. 6) 藻類が死滅しにくく、また RH $80 \%$ 以上の相対湿度がわずかに生じ たことで(Fig. 7)、藻類が徐々に増殖したと考えられる。

\section{3. 生物の増殖と死滅モデル}

以上の結果に基づき、藻類の増殖と死滅に影響を及ぼす環境因子 として日射量、壁表面温度、壁表面相対湿度に注目し、モデル化を 行う。

\section{1. 藻類の増殖 · 死滅モデル}

藻類の増殖 - 死滅モデルの基礎式として以下の個体群密度 $N$ の変 化に関する指数モデルを使用する $\left.{ }^{15)} 16\right)$ ここで、総合環境指数 $G$ は 日射量・温度・相対湿度が増殖に及ぼす影響を示すものとする。 $d N / d t=G r_{0} N$

$$
\left\{\begin{array}{lr}
G=g_{S} * f\left(g_{T}, g_{R}\right) & \left(0<T_{\text {surf }}<30\right) \\
G=g_{T} & \left(T_{\text {surf }} \leq 0,30 \leq T_{\text {surf }}\right)
\end{array}\right.
$$

$N$ ：個体群密度 [個 $\left./ \mathrm{m}^{2}\right], t$ ：時間 $[\mathrm{sec}], G$ ：総合環境指数 $[-]$,

$r_{0}$ : 成長率 $[1 / \mathrm{sec}], T_{\text {surf }}$ : 壁表面温度 $\left[{ }^{\circ} \mathrm{C}\right]$

$g_{S}, g_{T}, g_{R}$ : 日射量 - 温度 - 相対湿度に対応する環境指数 [-]

\section{2. 藻類の増殖と死滅に影響を及ぼす環境因子}

\subsection{1. 日射量}

気生藻類はクロロフィルにより光を吸収して光合成を行い増殖に 必要なエネルギーを得る。ただし、もともと光の届きにくい水中に 生育する藻類はわずかな光でも光合成を行う能力を持っている ${ }^{17)}$ 。 そこで、日射量に対応する環境指数 $g_{s}$ を Fig. 8 に示すように想定し、 閾值 $\mathrm{S}_{1}$ は非常に小さな值とする。日射による壁表面温度の上昇の影 響は温度の環境因子 $g_{T}$ で考慮する。

\subsection{2. 壁表面温度}

多くの藻類において、増殖最適温度は $18 \sim 25^{\circ} \mathrm{C}$ の範囲内にあり 13)、N. Häubnerら 18) は、Stichococcus sp.の最適温度は $21^{\circ} \mathrm{C} 、 C$. luteoviridisの最適温度は $24^{\circ} \mathrm{C}$ とている。また、辻本・大羽ら 1)3)

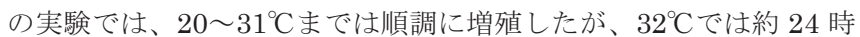
間後から徐々に緑色が失われ 72 時間ではほとんど死滅した。S. C. Agrawalら 13) 19) 20) 21) 22) は、 $40^{\circ} \mathrm{C}$ 以上の高温に数十分間暴露した場 合、藻類の細胞は死滅し再び増殖に最適な環境においても再活性化 はしないこと、暴露温度が高くなるほど、また暴露時間が長くなる ほど死滅する割合が大きくなることを実験により示している。そこ で本論文では、温度が $0^{\circ} \mathrm{C}$ 以下の場合には死滅、0〜 $30^{\circ} \mathrm{C}$ 範囲では 増殖可能、 $30^{\circ} \mathrm{C}$ 以上の高温においては死滅すると仮定し、Fig. 9 に 示すような温度に対応する環境指数 $g_{T}$ を想定した。

\subsection{3. 壁表面の相対湿度}

藻類にとって水分は生理学的に必要不可欠であり、光合成を行う 際にも必要とされる。ただし、気生藻類は雨や霧、結露といった大 気からの水分供給のみに頼って生長している藻類 ${ }^{6}$ )であり、水分条 件としては非常に厳しい環境下で生育している。そのため、乾燥状
態となった場合でもすぐに死滅せず、長期間生存する能力を持つ。 そこで、本論文では相対湿度が低下しても藻類はすぐに死滅せず、 再び増殖に最適な環境を得た際には増殖可能であると仮定する。そ こで、相対湿度 $80 \%$ 以下では増殖も死滅もせず、 $80 \%$ 以上では相対 湿度に比例して増殖率が増加し $100 \%$ で最大になるとして、Fig. 10 に示すような相対湿度に関する環境指数 $g_{R}$ を決定した。ただし、壁 表面温度が $30^{\circ} \mathrm{C}$ 以上になる場合には、相対湿度に関係なく藻類は死 滅するとしている。温度と相対湿度両方の影響を合わせた環境指数 を Fig. 11 に示寸。

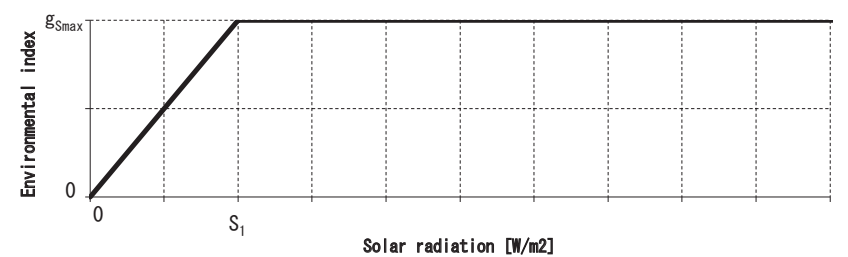

Fig. 8 Environmental index of solar radiation

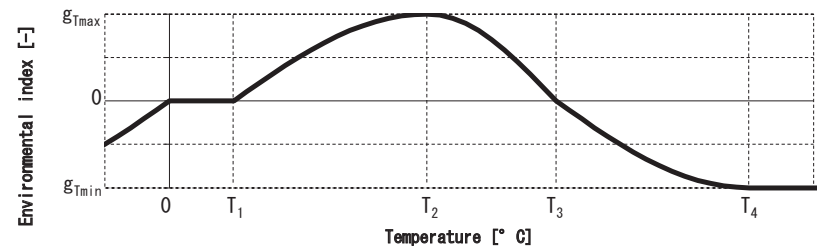

Fig. 9 Environmental index of temperature

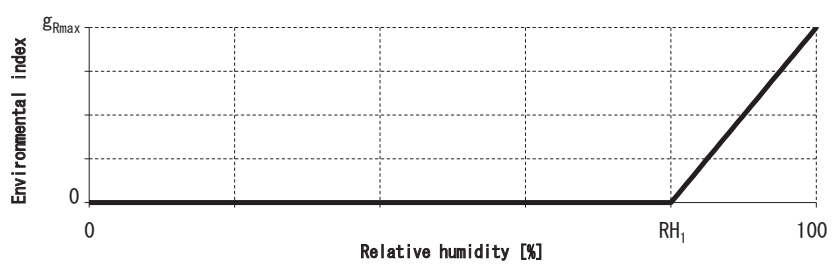

Fig. 10 Environmental index of relative humidity

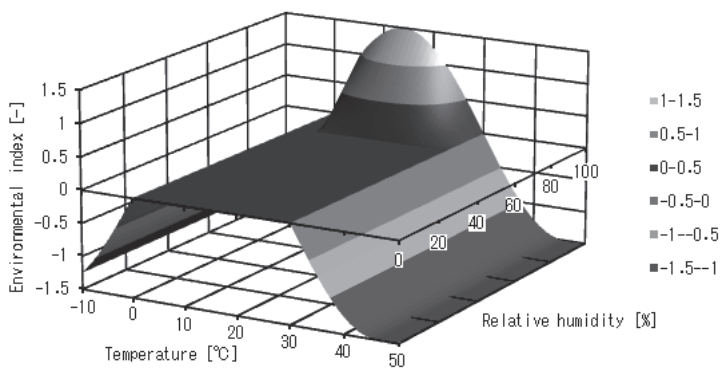

Fig. 11 Relation of environmental index between temperature and relative humidity

\section{3. 解析対象と解析条件}

解析対象は $\mathrm{L}^{*}$ 值の測定を行っている北壁、西壁上部と下部(西殿)、 東壁上部と下部(東殿)とし、2013 年 6 月 4 日から 2014 年 12 月 31

Table 1 Threshold values used for calculation of environmental index

\begin{tabular}{|l|c|c|c|}
\hline $\mathrm{N}_{0}$ (initial value) $\left[\mathrm{cell} / \mathrm{m}^{2}\right]$ & $1.0 \times 10^{6}$ & $\mathrm{~T}_{1}\left[{ }^{\circ} \mathrm{C}\right]$ & 5.0 \\
\hline $\mathrm{r}_{0}[1 / \mathrm{sec}]$ & $2.9 \times 10^{-7}$ & $\mathrm{~T}_{2}\left[{ }^{\circ} \mathrm{C}\right]$ & 20.0 \\
\hline $\mathrm{S}_{1}\left[\mathrm{~W} / \mathrm{m}^{2}\right]$ & 1.0 & $\mathrm{~T}_{3}\left[{ }^{\circ} \mathrm{C}\right]$ & 30.0 \\
\hdashline $\mathrm{g}_{\max }[-]$ & 1.0 & $\mathrm{~T}_{4}\left[{ }^{\circ} \mathrm{C}\right]$ & 45.0 \\
\hline $\mathrm{RH}_{1}[\%]$ & 80.0 & $\mathrm{~g}_{\operatorname{Tmax}}[-]$ & 1.5 \\
\hline $\mathrm{g}_{\text {Rmax }}[-]$ & 1.0 & $\mathrm{~g}_{\operatorname{Tmin}}[-]$ & -1.5 \\
\hline
\end{tabular}


日までの壁表面温湿度の測定值を用いた。ただし、北壁については、 2013 年 8 月から 12 月までの 5 か月間の測定から、東殿、中殿、西 殿の壁表面温度はほぼ等しい変化であり、日射による急激な温度上 昇はどの壁でも発生していないことが示されている。そのため、北 壁(中殿)での測定值を用いて考察を行う。日射量、温度、相対湿度 に対応する環境指数の閾值を Table 1 に示す。

\section{4. 解析結果}

2013 年 6 月 4 日から 2014 年 12 月 18 日までほぼ 1 か月に 1 回(全 19 回)測定を行っており、その測定日正午の藻類個体数と L*值を測 定回数(19 回)について平均したものをFig. 12 に示す。ただし、本 モデルでは $\mathrm{L}^{*}$ 值の変化傾向と藻類個体数の変化傾向(初期個体数に 対する割合) との対応を見るため、個体数については各時点での個体 数を計算開始時の個体数で除した相対值で示し、個体数と $\mathrm{L}^{*}$ 值の対 応を比較しやすく寸るため、 $\mathrm{L}$ *值の軸を反転している。

北壁は壁表面温湿度の測定を行った中殿北壁について代表して計 算を行っているため、北壁(東殿)と北壁(西殿)の違いは表現できてい ない。しかし、北壁(東殿)と東壁上部(東殿)の L*值はほぼ同じであ り、藻類の個体数も両部位でほぼ同様の值となっている点について はよく対応している。東壁(東殿)と西壁(西殿)の上部と下部について 比較すると、 $\mathrm{L}^{*}$ 值は上部より下部の方が大きく、藻類の個体数が小 さいことと対応している。ただし、東壁上部も下部も西壁よりも $\mathrm{L}^{*}$ 值が小さいことについては対応していない。

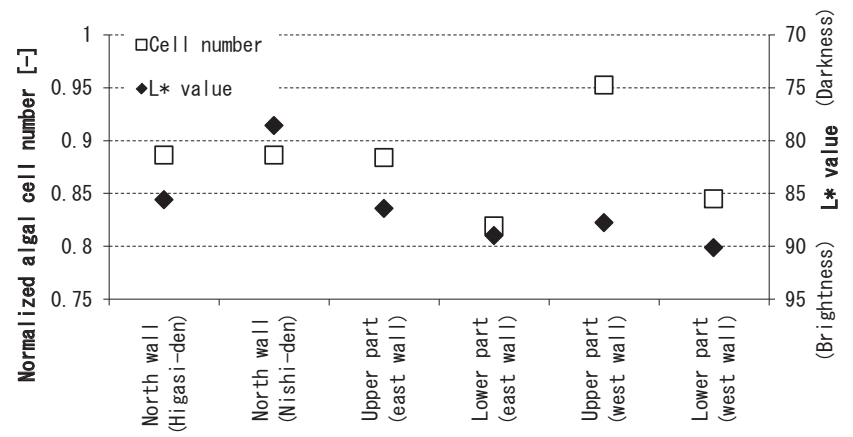

Fig. 12 Algal cell number and L* value of each wall part

次に、東壁上部と下部(東殿)、西壁上部と下部(西殿)、北壁下部の 解析により求めた藻類の個体数と $\mathrm{L}^{*}$ 值の 2014 年 6 月 4 日からの時 間变化を Figs. 13, 14，15 に示す。ただし、藻類個体数については 各時点での個体数を計算開始時の個体数で除した值を示し、個体数 と $\mathrm{L}^{*}$ 值の対応を比較しやすくするため、 $\mathrm{L}$ *值の軸を反転している。

\subsection{1. 東壁上部と下部 (東殿)}

2013 年 6 月 4 日の解析開始から 8 月までに L*值は上部が 4.3 、 下部が 4.1 増加しており、個体数の減少とよく対応している。個体 数の減少は 8 月末まで継続しているが、この期間は $\mathrm{L}$ *值を測定して いないが、個体数の変化と同様に L*值は増加していた可能性がある。 2013 年 9 月初めには L*值は上部が 2.9 、下部が 6.4 減少し、個体数 の増加も対応しているが、個体数の増加量に比べて L*值の減少量が 大きい。ただし、壁下部に対して壁上部の L*值の増加量の方がわず かに大きい点は、個体数の変化に対応している。また、壁上部では 2013 年 9 月末から 11 月末まで L*值が 1.2 減少しており、この部分 も個体数の増加と対応している。壁上部も壁下部も 2013 年 10 月半 ばから 11 月までの L*值の減少、2013 年 12 月から 2014 年 7 月の
L*值の増加も、個体数の変化と対応している。2014 年 8 月から 9 月にかけて L*值は上部が 1.6、下部が 0.2 増加しているが、個体数 も夏期の高温により減少している。

\subsection{2. 西壁上部と下部(西殿)}

全期間を通して、西壁上部の個体数が最も多く、 $\mathrm{L}^{*}$ 值の測定結果 とは対応していない。しかし、東壁上部・下部と同様に、2013 年 6 月 4 日の解析開始から 8 月まで個体数は大きく減少し、L*值が上部 で 3.3、下部で 2.1 増加したことに対応している。その後、2013 年 9 月初めに上部で 2.8 、下部で $3.1 、 L^{*}$ 值が減少した時期には、個体 数もわずかに増加している。ただし、東壁の場合と同じく L*值の変 化量に対して個体数の変化量は小さい。2013 年 9 月末に壁下部で は L*值は 1.5 増加し、個体数もわずかに減少している。その後は、 壁上部も壁下部も 2013 年 10 月半ばから 11 月までの L*值の減少、 2013 年 12 月から 2014 年 3 月までの L*值の緩やかな増加、2013 年 4 月から 7 月の $\mathrm{L}^{*}$ 值の減少も、個体数の変化と対応している。 2014 年 7 月半ばから 9 月に L*值は上部が 1.4 、下部が 1.3 増加し、 これと対応して個体数は減少し、その後ほぼ一定の值となっている。 3.4.3. 北壁

北壁(東殿)と東壁上部については、個体数の変化がほぼ同様であ り、 $\mathrm{L} *$ 值の測定結果と対応している。また、東壁、西壁と同様に、 2013 年 6 月 4 日から 8 月にかけて北壁(東殿)では 4.1、北壁(西殿) では 4.6 の L*值の増加と個体数の減少はよく対応している。9 月初

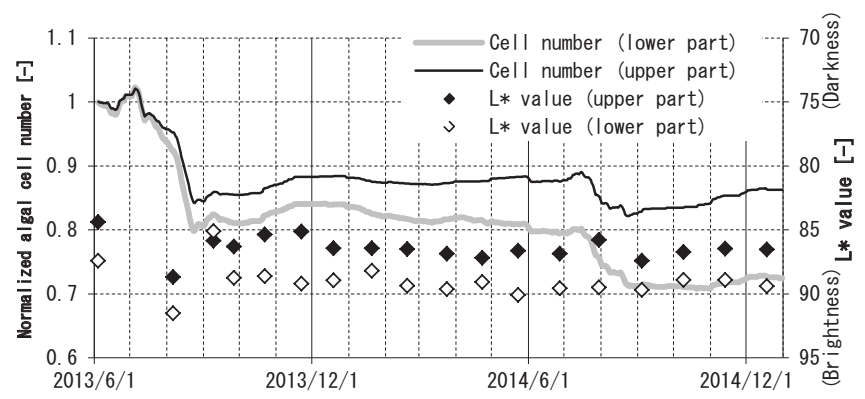

Fig. 13 Change of algal cell number and $L *$ value on east wall

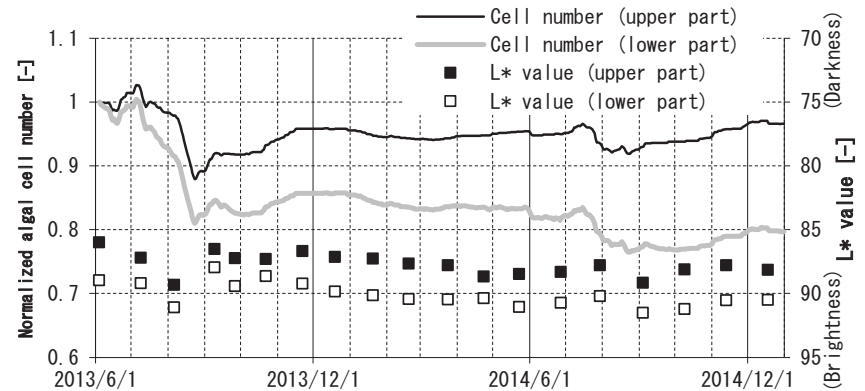

Fig. 14 Change of algal cell number and $L *$ value on west wall

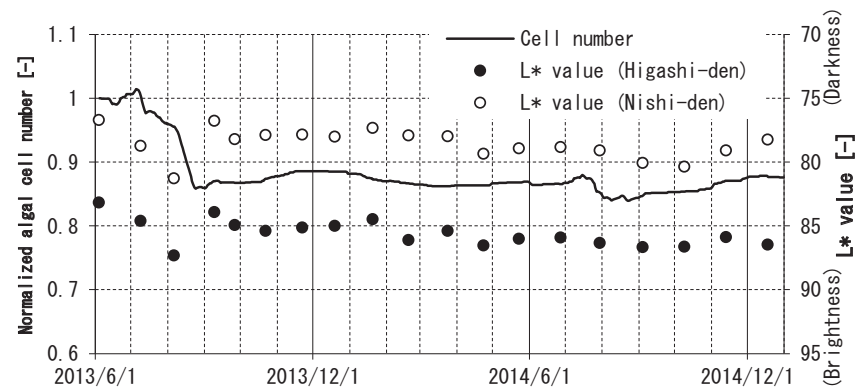

Fig. 15 Change of algal cell number and $L *$ value on north wall 
めに北壁(東殿)では 3.4、北壁(西殿)では 4.5、 L*值が減少した際に は、個体数はわずかに増加している。2013 年 10 月から 2014 年 6 月までは L*值は緩やかに増加し、同じく個体数も減少している。 2014 年 7 月から 8 月にかけて北壁(東殿)では 0.3、北壁(西殿)では 1.2、 $\mathrm{L}$ *值は増加し、その後ほぼ一定となる点も個体数の変化と対 応している。

\subsubsection{L*值と藻類個体数の変化との関係}

東壁上部と下部(東殿)、西壁上部と下部(西殿)、北壁の寸べての部 位において、藻類の個体数と L*值の変化傾向はおおよそ対応してい る。特に 2013 年 8 月の壁表面温度が高い時期の藻類個体数の減少 と、2013 年 11 月から 2014 年 7 月の緩やかな個体数の増加は、 $L^{*}$ 值の変化と対応している。ただし、2013 年 9 月初めに発生した L* 值の減少量に対して、藻類の個体数の増加量は小さく、この点につ いては更に検討が必要と思われる。

\section{4.まとめ}

仁和寺九所明神の壁表面における $\mathrm{L}^{*}$ 值(明るさ)測定より以下の結 果が得られた。

（1） L*值の変化には直前数日間の壁表面温湿度が大きく影響する。

- 夏期のように $40^{\circ} \mathrm{C}$ 以上の高温の発生頻度が高い時期には壁表面 の $\mathrm{L}^{*}$ 值は増加する。これは藻類の死滅が原因と考えられる。

- 高湿度が発生しても、日射により $40^{\circ} \mathrm{C}$ 以上の高温の発生頻度が 高い場合には、 L*值は増加する。

- 壁表面温度が $30^{\circ} \mathrm{C}$ 以上にならず、高湿度の場合には、 $\mathrm{L}^{*}$ 值は減 少する。

（2）壁表面の温湿度と(藻類による壁表面の污れ程度と相関の高 ()L*值の変化との対応より、藻類の増殖・死滅と温湿度の間には強 い相関があると考えられる。そのため、藻類の増殖率に影響を与え る因子として、壁表面の温度と相対湿度、壁表面に入射する日射量 に対応する環境指数を想定し、藻類の個体数増減について簡易なモ デルを作成した。

（3）提案するモデルを用いて解析を行った。

- 東壁・西壁の上部と下部、北壁について、2013 年と 2014 年夏 期の $\mathrm{L}^{*}$ 值の増加と解析により求めた藻類の個体数の減少、およ び 2013 年と 2014 年の 9 月から 10 月における L*值の減少と個 体数の増加はよく対応している。

・ $\mathrm{L}$ *值の変化量と個体数の変化量はまだ十分には対応していない 場合もあり、さらなる検討が必要であるが、作成したモデルにお いて、壁表面での藻類の増殖・死滅の傾向について十分説明が可 能である。

注

注 1 ) 仁和寺九所明神は、牡蠇、蛤、ほたて等の貝殼から作られた白色絵具 である胡粉を膠水と混ぜ塗装されている。そのため、本来の外壁面は白色 であり、本論文においては、污れの程度を明るさの指標である $L^{*}$ 值を用い て評価した。

\section{参考文献}

1）辻本吉寛, 大羽伸和, 須藤哲也：外壁面に発生する藻類の同定および藻 類污染方法の検討 建築物の外壁面における藻類污染に関する研究，日本 建築学会構造系論文報告集, 第 433 号, pp. 11-17, 1992.3

2) 大羽伸和, 辻本吉寛: 外装材料の藻類污染とその防止(第 1 報)污染の状況 と藻類の同定, 木材学会誌, Vol. 42, No. 6, pp. 589-595, 1996

3) 大羽伸和, 辻本吉寛 : 外装材料の藻類污染とその防止(第 2 報)屋内培羑実 験法の評価，木材保存，Vol. 22-4, pp. 22-29, 1996

4）北島洋二, 萩原清司, 越川義功, 柵瀬信夫 : 微細藻類を用いた外壁の緑 化研究，鹿島技術研究所年報，第 40 号, pp. 329-334, 1992. 10

5) 今村祐嗣：木質系材料の藻類污染と防止法(課題番号 07660221), 平成 7 年度 8 年度科学研究費補助金(基盤研究(C)(2))研究成果報告書, 1997. 3

6) 半田信司：気生藻類，堀輝三，大野正夫，堀口健雄編「21 世紀初頭の藻 学の現況」, 日本藻類学会, 山形, pp. 81-84, 2002

7）中嶋麻起子，鉾井修一，小椋大輔：建物外壁における藻類の生育状況に 関する研究，日本建築学会環境系論文集，Vol. 80, No. 710, pp. 331-337, 2015. 4

8）中嶋麻起子，鉾井修一，小椋大輔：仁和寺九所明神における藻類生育と 周辺環境との関係，ハウスクリマ研究ノート，第 39 号, pp. 23-30, 2013 6

9）中嶋麻起子, 鉾井修一, 小椋大輔：仁和寺九所明神における外壁の変色 状態と周辺環境との関係, 日本建築学会大会学術講演梗概集 D-2 環境工学 II , pp. $87-88,2014.9$

10）福田敏朗著, 中尾正治編: 重要文化財仁和寺九所明神修理工事報告書, 京都府教育庁指導部文化財保護課，2006. 3

11）中嶋麻起子, 鉾井修一, 小椋大輔 : 仁和寺九所明神における藻類生育と 周辺環境との関係, 日本建築学会環境系論文集, 第 80 巻, 第 713 号, pp. 575-581, 2015. 7

12) Gupta, S. and Agrawal, S. C.: Vegetative Survival and Reproduction under Submerged and Air-Exposed Conditions and Vegetative Survival as Affected by Salts, Pesticides, and Metals in0 Aerial Green Alga Trentepohlia aurea, Filia Microbiol., 49(2), pp. 37-40, 2004

13) Gupta, S. and Agrawal, A. C.: Survival of Blue-Green and Green Algae under Stress Conditions, Folia Microviol., 51(2), pp. 121-128, 2006

14) Gupta, S. and Agrawal, S. C.: Vegetative Survival of Some Wall and Soil Algae under Stress Conditions, Folia Microbiol., 53(4), pp. 343-350, 2008

15）有田正光編著：生物圈の環境, pp. 21-24, 東京電機大学出版局, 2007 16）宮内真紀子，鉾井修一，宇野朋子，小椋大輔：高温多湿気候下における 遺跡一の藻類による影響, 日本建築学会環境系論文集，第 73 巻，第 623 号, pp. 9-15, 2008. 1

17） W. M. ダーリー: 基礎微生物学 9 藻類の生理生態学, pp. 29-36, 52-56, 培風館, 1987

18) Häubner, N., Schumann, R., and Karsten, U.: Aeroterrestrial Microalgae Growing in Biofilms on Façades - Response to Temperature and Water Stress, Microbial Ecology, Vol. 51(3), pp. 285-293, 2006. 4

$19)$ Agrawal, S. C. and Singh, V.: Vegetative Survival, Akinete Formation and Germination in Three Blue-Green Algae and One Green Alga in Relation to Light Intensity, Temperature, Heat Shock and UV Exposure, Folia Microbiol., 45(5), pp. 439-446, 2000

20) Agrawal, S. C. and Singh, V.: Viability of dried cells, and survivability and reproduction under water stress, low light, heat, and UV exposure in Chlorella vulgaris, Israel Journal of Plant Sciences, Vol. 49, Issue 1, pp. 27-32, 2001

21) Agrawal, S. C. and Singh, V.: Viability of Dried Filaments, Survivability and Reproduction under Water Stress, and Survivability Following Heat and UV Exposure in Lyngbya martensiana, Oscillatoria agardhii, Nostoc calcicola, Hormidium fluitans, Spirogyra sp. and Vaucheria geminata, Folia Microbiol., 47(1), pp. 61-67, 2002

22) Agrawal, S. C. and Pal, U.: Viability of Dried Vegetative Cells or Filaments, Survivability and/or Reproduction under Water and Light Stress, and Following Heat and UV Exposure in Some Blue-Green and Green Algae, Folia Microbiol., 48(4), pp. 501-509, 2003 


\section{Makiko NAKAJIMA*, Shuichi HOKOI**, Daisuke OGURA*** and Chiemi IBA ****}

\footnotetext{
* Grad. Stud., Dept. of Architecture and Architectural Eng., Graduate School of Engineering, Kyoto University, M.Eng.

** Prof., Dept. of Architecture and Architectural Eng., Graduate School of Engineering, Kyoto University, Dr.Eng. *** Assoc. Prof., Dept. of Architecture and Architectural Eng., Graduate School of Engineering, Kyoto University, Dr.Eng. **** Assist. Prof., Dept. of Architecture and Architectural Eng., Graduate School of Engineering, Kyoto University, Dr.Eng.
}

One of the main causes underlying the soiling of exterior walls is the presence of airborne algae. The present study aims to quantify the relationship between airborne algal growth and/or death on the exterior walls of the building and the associated environmental factors. Accordingly, the study proposes a prediction model of the algal growth, wherein the algal growth is evaluated as algal cell number. In particular, the proposed model was used to simulate the change in algal cell number.

According to our previous studies, soiling occurred not only on the parts that were directly exposed to the rainwater but also on the parts that rarely received the rainwater. However, algal cells were observed on both the parts, irrespective whether or not they were exposed to rainwater. The degree of the soiling could be quantitatively evaluated using the $L^{*}$ value of the wall surface, which is a function of its brightness. On the parts where the high temperatures reach above $40^{\circ} \mathrm{C}$, the algae could not grow and were liable to die. Consequently, the wall surfaces were barely discolored, contributing to larger $\mathrm{L}^{*}$ value, and vice versa.

Accordingly, the algal growth and death is presumed to proceed as follows. In general, the algae can adhere to every part of the exterior surface. However, they are prone to die and the soiling cannot be significant on the parts with high temperatures and low humidity due to the solar radiation. On the contrary, the algae can grow and the soiling proceeds on the parts without the high temperatures and low humidity.

On the basis of these results, regarding the relationship between the $\mathrm{L}^{*}$ value and temperature and humidity of the wall surface, the following can be concluded.

(1) The change in environmental conditions significantly affected the $L^{*}$ in the previous several days, that is, - when the surface temperatures frequently reached $40^{\circ} \mathrm{C}$, there was an increase in the $\mathrm{L}^{*}$ value, probably due to the algae death,

- when the surface temperatures rarely reached $40^{\circ} \mathrm{C}$, together with high surface humidity, there was a decrease in $\mathrm{L}^{*}$ value,

- when the surface temperature reached $40^{\circ} \mathrm{C}$, there was an increase in $\mathrm{L}^{*}$ value, despite the high surface humidity due to the rainfall.

(2) The abovementioned strong correlation between the environmental factors (surface temperature and humidity) and $L^{*}$ value indicates that the algal growth/death is significantly influenced by the temperature and humidity during the past several days. Based on these, we proposed a simple algal growth/death model, taking into consideration the influence of the surface temperature, humidity, and incident solar radiation.

(3) The following results were obtained based on the simulation performed using the proposed model. On the east, west, and north walls, the increase in the $L^{*}$ values corresponded to the decrease in the algal cell number during summer of 2013 and 2014. From September to October of 2013 and 2014, the decrease in L* values corresponded to the increase in the algal cell number. 